\title{
UNDERGROUND WATERS: CHANGES IN GROUNDWATER POLICIES
}

\author{
FRANCINE CANSI ${ }^{1} \&$ JOAQUIN MELGAREJO MORENO ${ }^{1,2}$ \\ ${ }^{1}$ Juridical Science, Instituto Universitario del Agua y Ciencias Ambientales (IUACA), Spain \\ ${ }^{2}$ History, University of Murcia, Spain
}

\begin{abstract}
The 1988 Constitution of Brazil used the expression "water resources", not translating its economic use, but as being for the general enjoyment of the collectivity, the populace. Debates on issues related to underground water availability as another source of the water supply have raised major concerns about the quantity, quality and depletion of this resource. Even using this tuning fork, this hydrogeological body of water remains in a situation of scarcity, in the same way as the superficial waters, because the knowledge of the subject is still hindered. In Brazil, for example, the distribution of water is far from homogeneous, although there is a government effort to protect this reservoir. The greatest challenge in terms of water resources conservation lies in the lack of effective mechanisms to control, protect and use these natural resources without impeding the economic growth of the country. On the other hand, the concept of there being a water crisis goes beyond scarcity, resulting from a combination of governance failures, environmental preservation, sustainability issues and disparity in access to water. While the human right to water requires the use of this sensitive and exhaustible resource, there is an obligation for states to ensure there is secure access and secure storage, and there is a need for a more active role of sustainability to be present in society at large; however, the underground water use and management reiterate the same flaws that lead to surface water degradation. In addition, the deliberate use of groundwater requires rational actions, as resource allocation is as important in equity, which is often crucial in governance decisions. In order to understand groundwater policies, it is imperative to understand the structure and actual sequence of events by analyzing the factors or attributes that make groundwater management successful in some regions, but not others. Keywords: global water, governance, groundwater policy, human rights, water policy, water use.
\end{abstract}

\section{INTRODUCTION}

The adoption of a real model for sustainable development, in particular in the management of groundwater, requires a profound change of consciousness, of the way humans perceive and understand the dependence of their life upon the natural environment; as well as lead to that sustainable model, suppressing old structures and paradigms, so that instead there is a reconstruction of a novel civilization, based on the central value of sustainability for reconstruction or transformation, in which it presents emerging options in different latitudes of the globe for the protection of waters. Baumann [1] cites for this argument that "to seek water, to wash clothes, to exchange information and opinions..." by which one agrees, because in this concept of the new demands of globalization, that if on the one hand you seek deep transformations in social systems, stimulating sustainable strategies, according to the three pillars of sustainability; on the other hand, there seems to be no concrete efforts to overcome the water crisis.

It is affirmed that there is support for the work "Manifesto for Democracy on Earth, Justice, Sustainability and Peace" [2], so the exhaustion of the land, the exploitation of groundwater, the erosion and extinction of biodiversity are succumbed by a lack of governance in the conservation of surface and underground water resources. In addition, in the world scenario, one in three inhabitants suffers from water shortages: for every 1000 liters of water used, another 10,000 are polluted. By 2025, 1.8 billion people are expected to 
live without water; and only $0.007 \%$ of the total water on the planet will be fit for consumption [3].

The connection of these unresolved problems into a larger problem lies in the illusion that nature is self-sufficient, available, abundant; and that water resources, still treated in a peripheral way, evidenced the consequences of their irrational exploitation, in which the implications represent irreversible damages to what should be a vital resource for living beings [4].

In regarding adaptation strategies, it is important to identify and understand production systems that have high resilience to extreme climatic conditions, as these systems can serve as a source of learning and inspiration for the elaboration of strategies to adapt to climate change [5]. If it is no longer possible to prevent climate change from occurring in the next two or three decades, it is still possible to protect our societies and economies from those impacts: for example, by providing quality information, more resilient production systems, improved planning and infrastructure [6]. Therefore, a discussion about the factors or attributes that make groundwater management successful in some regions and not others is the object of this study. This is because it is no longer acceptable for a single organism to decide multiple environmental issues, especially the management and policies surrounding groundwater.

\section{A SEMANTIC ISSUE: WATER RESOURCES OR WATER?}

The term water serves the natural element, the common good, and is deprived of economic value, just like the waters of rivers, lakes and oceans; whereas, a query of water's character brings a designation of the mercantile use, like the water that is supplied to houses, industries and irrigation for farming. Water as a natural element can be considered free of any use or used, since the water resource is water as an economic unit; however, there is still a conceptual absence between water and water resources; since their legislation makes no distinctions. In addition, water when specifically intended for activities carried out by human beings, becomes a water resource. Added to this concept, the groundwater, found in the saturated zone of the ground, is often denominated like a "poor relative" of the superficial waters [7]. Nevertheless, its operational nature in maintaining ecosystems, for the survival of mankind, accounts for about $97 \%$ of the fresh water available on the planet [8]. What refers to the rights to groundwater, has made this natural resource vulnerable to degradation and exhaustion, which occurs mainly due to the deficiency of a peculiar legal regime of management and protection, because these waters constitute the main source of drinking water: for example in Europe, $70 \%$ of drinking water and in Brazil $15.6 \%$ of the water consumed are from underground sources [9].

In addition, groundwater represents a maintenance function within the hydrological cycle [10]. A fraction of the condensed water returns to the waterways by way of precipitation, or it infiltrates the natural fissures of the soils and rocks, forming the reserves of groundwater that usually return to feed the superficial waters. This balance maintains the renewal of water, and its ecological, biological and thermal functions. The increase in the use of water, in particular underground water, confers human vulnerability onto the balance of the hydrological cycle [11].

It is emphasized that groundwater-free aquifers are those that have a physical connection with surface waters, the holdings are not directly linked to surface waters. This is a criterion that characterizes the aquifers; therefore, indicates the most appropriate management and protection regime. This criterion leads to the understanding that free groundwater is vulnerable to pollution and depletion [10]. This is a fundamental distinction, for a management regime, since this relationship must obligatorily glimpse the relationships 
between them. With this, information failures, and global and national inequalities that have influenced a new order to reach the whole of society; there is a need for combining decisions and actions to regulate economic activities for the preservation of groundwater [12].

\section{THE SUSTAINABILITY DEBATE IN THE SOCIAL CONTEXT AND GOVERNANCE POLICIES}

Recognition by a government, or by citizens, of the need for government action is one of the initial steps to create or change a policy. In both political-ideological and practical terms, global governance of development was only born, in fact, a quarter of a century ago, with the rearrangement after the defeat of Nazi fascism. In summary, it is very clear from this rapid overview of the main scientific work that references global ecological boundaries may have been well identified, but that there was no achievement of comparable success in seeking to demarcate them. This fact obviously complicates the noble ambition of not violating these boundary rules, and even more of which environmental changes are really "unacceptable." Even 20 years after its consecration in Rio de Janeiro, the celebrated sustainable development agenda, which was pompously titled "Agenda 21 " has not engendered an even reasonable level of environmental governance [13].

There were countless historical experiences, diplomatic attempts, contemporary movements and actions that have tried to take care of the generation of sustainability, to recover the practices, attitudes and ways of promoting technologies that make us effective and efficient; but to value the role of people in nature, human dignity, empathy, cooperation, equity and commitment. Water, as the essence of sustainability, evaporates, moistens the atmosphere, absorbs ecosystems or covers them with dew. But not only by its watering nature, but because it embodies equity, bathes social justice, penetrates the ecological economy, and involves the human being and the biosphere. This water makes care of nature flourish and mature, brings individual and social transformations, human development; and therefore, universal education, health coverage, culminating in human rights and cultural understanding, which in turn will enable a significant reduction of poverty, real gender equality, coherent eco-technological production, ethically responsible consumption, and attention to diversity and biodiversity. Given this thought, once recognizes the need to create or change a policy that is necessary to effectively implement the management of water resources, in particular groundwater, based on real criteria of accessibility, feasibility and availability, to achieve objectives and goals, adopting in the foreground the change of certain past behaviors [12]. As Morin argues "The techno-economic unification of the globe is in crisis. There is a coincidence between the proliferation of sovereign states, the growth of their interdependence and their ethno-religious closure. This coincidence is not fortuitous. It is explained: a) by the national, ethnic and cultural resistance to Westernization; b) the general fall of the hope placed in Progress. Western civilization itself, which produces the crises of globalization, is in crisis. The selfish effects of individualism destroy old solidarities. A psychic and moral malaise settles at the heart of material well-being. Consumerist intoxications of the middle classes develop, while the situation of the underprivileged classes degrades and inequalities worsen. The crisis of Western modernity makes modernizing remedies for crises oblivious" [14].

The maturity of civilization will undoubtedly be tested by its capacity to overcome the various current environmental crises through concretization and a spirit of cooperation, as well as a sustainable governance system [15]. What is at stake is the way of living hereafter on this planet, within the context of the acceleration of technical-scientific mutations and considerable population growth. There will be no real response to the ecological crisis, except on a planetary scale and on the condition that an authentic political, social and cultural 
revolution be undertaken, reorienting the objectives of the production of material and immaterial goods. This revolution must, therefore, concern not only the relationships of forces visible on a large scale, but also the molecular domains of sensibility, intelligence and desire. Only a joint action that establishes a collective feeling of affiliation with the entire biosphere will give the opportunity to secure the future. For this, it will be necessary to develop a biospheric consciousness. The empathic civilization begins to emerge, enlarging the whole of a vast project of life that encompasses the planet [16].

The governments are concerned about this, due to the fact that social problems have increased considerably, and consequently environmental problems, and government, as the body responsible for solving them, has not been able to go along hand in hand with the difficulties. The key element in finding solutions to new environmental problems is the promotion of green technologies. For this reason, science and technology occupy a special place in the new environmental policy, necessitating new resources to deal with the ecological crisis. In sum, the perspective of ecological modernization has focused on the new role that science and technology acquire in transforming advanced societies in the face of environmental challenges. There is an impact on the role of science in creating technological innovations that allow prevention and also the solution of environmental problems. It is difficult to imagine a future in which scientific activity plays a central role in the economic, political and cultural terrain of societies. Yet science and technology are not isolated elements, nor the only engine of social change [17].

The way an economy is managed has an impact on the environment; which, in turn, affects both the well-being of the inhabitants and the performance of the economy. Arguing that economic growth leads to environmental degradation and inequalities in wealth, the economy is a subset of our finite environment. As the development of human societies steadily increased and technology has developed increasingly rapidly, so has pressure on the environment. Fueled by an uncontrolled global economic system, which has created so much unprecedented wealth (through excessive consumption) and also huge levels of poverty and environmental problems, these now threaten to increase inequalities and cause irreversible damage to ecosystems on a global scale. Irrevocably, our planet is slowly but surely dying, the ozone layer is running out and global warming has become more evident than ever; leading to drought, famine, flood, misery and disease [18]. There are numerous reasons that cause environmental warming, but the most fundamental cause above all else is the unconsciousness of people about the vital role the environment plays in our life. Undeniably, humans are the most serious culprits of these changes.

Besides the problems of population growth and availability of resources are the issues of environmental depletion, especially of water resources. Unless massive transformations begin toward environmentally sustainable development paths within this decisive decade, environmental deterioration and economic decline will be fueling us, pulling us into social and political decay [14].

Given that there is planetary economic and ecological interdependence, no nation nor income class can isolate itself from the adverse effects of a world experiencing population growth induced by mass poverty, by the destruction of resources driven by excessive consumption and large-scale socio-political disintegration. This obviously also includes corporations, which are totally dependent on the natural world for their resources and livelihood, and on the social world for stability and security.

In the search for alternatives to human development, and thinking about the environmental aspects, one can see the depletion of natural resources, more frequent and intense disasters, loss of biodiversity, environmental degradation, and the negative impact of the increase in global temperature as well as the level of the sea, it makes sense to balance economic 
development with environmental sustainability and social justice, which is a challenging and complex issue that must be tackled in a systemic way [18]. Managing common equity means making a more integrated use of the human component with the physical component. This necessarily involves a protective attitude towards the environment, which imposes its corrections to the model of sustainable economic development, in order to guarantee the maintenance of the biological balances that are indispensable to the great global balance of the planet. Therefore, it is a citizen conscience directed toward essential attitudes, as a more rational and responsible use of water resources and others from nature, which are not inexhaustible; respect for life in all its forms; reconstruction of that which has been destroyed and adoption of preventive measures [10].

\section{ENVIRONMENTAL POLICY OF FREQUENCY GROUNDWATER}

The definition of the environmental policy of groundwater is not consensual, because of the breadth of scope of these policies. It covers the complex set of actions and relationships between humans and biodiversity, and all that affects the quality or use of natural resources. As the means to achieve sustainability is premised on modifying personal attitudes and practices; one must allow communities to take care of their own environment, generate a national structure for the integration of development and conservation, and form a global alliance, such as for air and water pollution control [19].

Environmental policies require a determination of the new priorities defined by society, through a new ethic of human behavior and a recovery of social, collective interests, encompassing a set of key changes in the structures of production and consumption, reversing the environmental degradation framework and the social misery it causes, which is not currently occurring. It requires government action focused on new approaches to sustainable development, an objective that requires a balance between "three pillars": the economic, social and environmental dimensions [10]. As well as the capacity and means to effectively combat environmental abuses of either air, soil or waterways.

There is an indispensable need to gather guidelines, principles, strategies, programs and actions to be adopted globally, nationally and locally, and these can be defined as "a planning tool for the construction of sustainable societies", recognizing the "Principle of Supremacy of Interest Public in the Protection of the Environment in Relation to Private Interests". This principle is, in reality, a general principle of modern Public law, by which the superiority of the collective interests is proclaimed, which should prevail over the interests of individuals. It is, in fact, a true assumption of the stability of a social order in which water resources are embedded as a common good [19].

An environmental policy should contribute to minimizing risks and human activities that threaten the health or life of humans or ecosystems; however, it must still be the result of an immense collective effort to transform the environment, which has now become an imaginary war of conquest, dominated by wild nature. Human activities have infinitely surpassed nature's ability to restore its destroyed and consumed elements, and there is unsustainable exploitation of waters [20]. Traditional management aimed at ensuring more rigid regulation has shown that it is impossible to guarantee dignity to people if a healthy environment is not ensured, and it is impossible even to ensure human life without an environment conducive to its development [21]. Alongside social rights, which have been called second-generation rights, today the so-called third-generation rights have emerged, which constitute a category, to tell the truth, still excessively heterogeneous and vague, which prevents us from understanding what effectively can treat the situation. The most important of these is the one claimed by ecological movements: the right to live in an environment that is not polluted [22]. 
Sustainable development for the protection of groundwater would therefore result in a double pact: a management pact that translates into a constant concern for the conservation and preservation of resources for future generations; and a pact of social organizations expressly concerned about meeting the basic needs of all humans. In addition to social equity and ecological balance, sustainable development presents the third major issue, the issue of economic development. It induces a spirit of common responsibility as a process of change in which the exploitation of material resources, financial investments and technological development routes should acquire harmonious meaning [23]. National environmental policies, as well as international actions for the promotion of sustainability, become public function oriented, for the integrated specialization of the different sectorial policies that intervene in a given territory, and among them, a water resources policy can be executed that considers groundwater as a common heritage, one which means to make integrated use of the human component with the physical component. This necessarily involves a protective attitude of the environment, which imposes corrections to the model of sustainable economic development, in order to guarantee the maintenance of biological balances indispensable to the greater global balance of the planet [20].

With this, a citizen conscience directed to essential attitudes should become established, such as: more rational and responsible use of natural resources that are not inexhaustible; respect for life in all its forms; reconstruction of what has been destroyed; and adoption of preventive measures, including emerging actions, in order to prevent gaps in the use of water resources and ensure the full cooperation of nations, through new and transforming aspects for sustainable development [13]. With this motivation in mind, the challenges to be highlighted lie within the scope of shared action, for the adoption of a shared responsibility, constituting proposals that integrate all the scales, be they municipal, national or global, of environmental policies that are more effective at protection of groundwater; as well as the implementation of a global political consensus, providing a focus for advocacy, improving the targeting and flow of aid, as well as the follow-up of development projects that provide a reference to address the most pressing social challenges in the world, with a priority focus on meeting basic human needs, access to and availability of water use in a truly sustainable way [23]. In this argument, groundwater protection policies can help public understanding of the complex challenges for sustainable development, inspiring public and private action, promoting integrated thinking and encouraging accountability. The challenges addressed are inherently integrated, so sustainable development will require actions together rather than individually or one at a time. Thus, efforts will be necessary so that social participation does not end up being only a form of bureaucratic legitimization of the decisions that were previously taken.

\section{FINAL CONSIDERATIONS}

Debates on issues related to underground water availability as a source of water supply have raised major concerns about the quantity, quality and depletion of this resource. In this context, the greatest challenge in terms of water resource conservation lies in the lack of effective mechanisms to control, protect and use these natural resources, without impeding the economic growth of the country. On the other hand, the concept of a water crisis goes beyond scarcity, the result of a combination of failures of governance, environmental preservation, sustainability and disparity in access to water. The different countries will have to present different degrees of attention and effort to incorporate the human right to water; guaranteeing safe access, replenishment of the aquifer's storage capacity, and the need for a more active role of sustainability in society, requiring actions of rationality, as important in resource allocation as in equity, which is often a crucial element in governance decisions. 
Therefore, implementing effective water resource management policies is not a common process, since it establishes the participation of values and that depend fundamentally on the resources made available by nature, on the maintenance and sustainability of water resources, aiming at collective sustainability in order to create legal and public policies of sustainable development, allied to the system of government founded constitutionally in accordance with the dictates of social justice, politics and health.

\section{REFERENCES}

[1] Bauman, Z., Globalização: As Consequências Humanas (Globalization: Human Consequences), trans. M. Penchel, Zahar: Rio de Janeiro, p. 32, 1999.

[2] Shiva, V., Manifiesto para una Democracia de la Tierra. Justicia, Sostenibilidad y Paz (Manifesto for Democracy on Earth, Justice, Sustainability and Peace), Paidós: Barcelona, pp. 221-217, 2006.

[3] Associação Brasileira de Águas Subterrâneas (ABAS), Águas subterrâneas (Groundwater), Campinas, SP, 2007.

[4] Amaral, S. et al., Comunidades ribeirinhas como forma socioespacial de expressão urbana na Amazônia: uma tipologia para a região do Baixo Tapajós (Pará-Brasil) (Riverine communities as a socio-spatial form of urban expression in the Amazon: a typology for the region of the lower Tapajós (Pará-Brazil)). Rev. Bras. Est. Pop., 30(2), pp. 367-399, 2013.

[5] de Santos, B. \& Garavito, C.A.R. (eds), El Derecho y la Globalización desde Abajo: Hacia una Legalidad Cosmopolita (Rights and Globalization from below: Towards Cosmopolitan Legality), Anthropos: Barcelona, p. 340, 2007.

[6] Irigaray, C.T.H., Água: um direito fundamental ou uma mercadoria? (Water: A fundamental right or a commodity?) Congresso Internacional de Direito Ambiental: Direito, ed A.H. Benjamin, Água e Vida, Imprensa Oficial: São Paulo, p. 118, 2003.

[7] McCaffrey, S.C., The contribution of the UN Convention on the law of the nonnavigational uses of international watercourses. International Journal of Global Environmental Issues, 4(3), pp. 250-263, 2001.

[8] Salif-Diop, P.R., Atlas Mondial de l'Eau: Une Pénurie Annoncée (World Atlas of Water), Autrement/PNUE/Mémorial de Caen: Paris, p. 16, 2003.

[9] Chazournes, L.B., Eaux internationales et droit international: vers l'idée de gestion commune, Recueil des Cours de l'Academie de la Haye, p. 34, 2005.

[10] Granziera, M.L.M., Direito de Águas: Disciplina Jurídica das Águas Doces (Water Law: Legal Discipline of Sweet Water), Atlas: São Paulo, p. 64, 2001.

[11] Machado, P.A.L., Recursos Hídricos. Direito Brasileiro e Internacional (Water Resources. Brazilian and International Law), Malheiros: São Paulo, p. 55, 2002.

[12] Estevan, A.E. \& Naredo, J.M., Ideas y Propuestas para una Nueva Política del Agua en España, Fundación Nueva Cultura del Água: Bilbao, p. 119, 2004.

[13] Veiga, J.E., Indicadores de sustentabilidade (Sustainability indicators). Estudos Avançados, 24(38), pp. 39-52 and p. 112, 2010.

[14] Morin, E., A Via para o Futuro da Humanidade (The Way to the Future of Humanity), 2nd ed., Tradução de Edgard de Assis Carvalho, Mariza Perassi Bosco, Bertrand Brasil: Rio de Janeiro, pp. 23-26, 2015.

[15] Berggruen, N. \& Gardels, N., Governança Inteligente para o Século XXI (Intelligent Governance for the 21st Century), Prisa Edições: Rio de Janeiro, p. 236, 2013.

[16] Rifkin, J., La Civilización Empática (Empathetic Civilization), Paidós: Barcelona, p. $606,2010$. 
[17] Beck, U., La Sociedad del Riesgo: Hacia una Nueva Modernidad (The Society of Risk: Towards a New Modernism), Ediciones Paidós: Barcelona, pp. 20-12, 1998.

[18] Riechmann, J., Reyes, L.G., Herrero, Y. \& Madorrán, C., Qué Hacemos Hoy cuando nos Encontramos Frente a la Amenaza de una Crisis Mayor que la Económica: La Ecológica (What to do Today when Faced with the Threat of a Crisis Larger than Economic: Ecologic), Ediciones Akal: Madrid, pp. 10-11, 2012.

[19] Dye, T.R., Understanding Public Policy, Prentice-Hall: Upper Saddle River, p. 107, 2002.

[20] Jacobi, P.R. \& Barbi, F., Democracia e participação na gestão dos recursos hídricos no Brasil. Katálysis:Florianópolis, 10(2), pp. 237-244, 2007.

[21] Jorgensen, S.E. \& Rast, W., The use of models for synthesizing knowledge for integrated lake basin management, and facilitating implementation of the World Lake Vision. Lakes and Reservoirs, 12, pp. 3-13, 2007.

[22] Dasgupta, P., The idea of sustainable development. Sustainability Science, 2, pp. 511, 2007.

[23] Varela, C.A., Instrumentos de políticas ambientais, casos de aplicação e seus impactos para as empresas e a sociedade. Revista Ciências Administrativas Fortaleza, 14(2), pp. 251-262, 2008. 